\title{
POLITICAL RISK OF SOCIAL SECURITY: THE CASE OF THE INDEXATION OF BENEFITS IN THE CZECH REPUBLIC
}

\section{Libor Dušek}
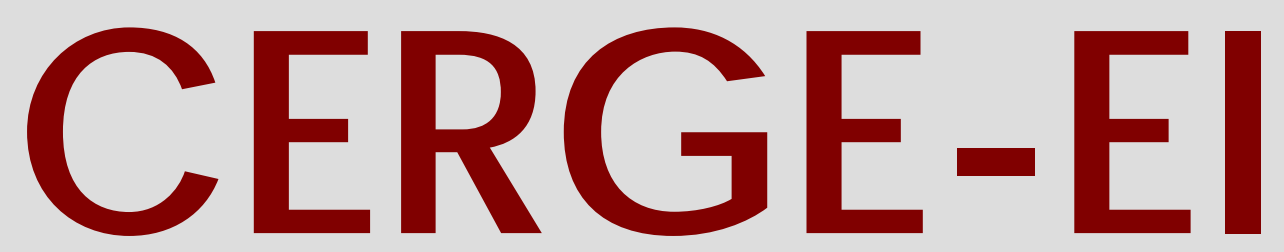

Charles University CenterforEconomic Research and Graduate Education Academy of Sciences of the Czech Republic Ec onomic s Institute 


\section{Working Paper Series 318 (ISSN 1211-3298)}

\section{Political Risk of Social Security: The Case of the Indexation of Benefits in the Czech Republic}

Libor Dušek

CERGE-EI

Prague, March 2007 
ISBN 978-80-7343-115-0 (Univerzita Karlova. Centrum pro ekonomický výzkum a doktorské studium)

ISBN 978-80-7344-104-3 (Národohospodářský ústav AV ČR, v. v. i.) 


\title{
Political Risk of Social Security: The Case of the Indexation of Benefits in the Czech Republic
}

\author{
Libor Dušek*
}

\begin{abstract}
We contribute to the literature on the political risk of social security by extending Feldstein and Ranguelova's (2001) methodology for measuring risk in a funded pension system to a pay-as-you-go system. We use the methodology to assess the risk over indexation of benefits in the Czech Republic during the 1990's and early 2000's. The government's discretion over indexations creates both aggregate and individual risk and makes the Czech Republic a particularly interesting case to study. Using data on the actual evolution of benefits for people who retired between 1988 and 1995, wre find that retirees faced fairly large volatility in the changes in real benefits - while the mean percentage change was 1.2, its standard deviation was 4.3. This volatility reduces the expected utility of retirees by 0.8 to 1.3 percent of equivalent consumption.
\end{abstract}

\begin{abstract}
Abstrakt
Článek prispívá do rozvijející se literatury o politických rizicích průběžnè financovaného penzijnúho systému. Rozšiřuje metodologii Feldsteina and Ranguelové (2001), pưvodně odvozené $k$ mēr̃ení rizika fondově financovaného sysstému, na systém financovaný prưběžně. Metodologie je použita ke lrvaṇtifikaci rizika voplýrajícího z valorizace důchodi̊ v České republice na konci 20. a počátlu 21. století. Diskrece vlády ohlednē valorizace důchodi̊ vytvârí agregátni i individuální nejistotu, díky čemuž je český penzijní systém obzviáśt? náchylný k politickému riziku. Na základĕ analýzzy dat o skutečném vjrvoji důchodů lidí, kteří odešli do důchodu v letech 1988 až 1995, zjištujueme, že důchodci jsou vystaveni pomèrně značné volatilitiě reálné hodnoty svớch důchodi̊: zatímco průmērná procentuální zmēna byla 1.2 , její směrodatná odchyllka byla 4.3 . Tato volatilita snjžuje očekávaný užitek dúchodcư o 0.8 až 1.3 procent ekvivalentní spotřeby.
\end{abstract}

Keywords: social security, political risk, pension reform JEL Codes: H55, D72

CERGE-EI is a joint workplace of the Center for Economic Research and Graduate Education, Charles University, and the Economics Institute of the ASCR, v. v. i.

Address: CERGE-EI, P.O. Box 882, Politických věžı̊ 7, Prague 1, 11 21, Czech Republic

Email address: libor.dusek@@cerge-ei.cz. I appreciate comments and suggestions from Randall Filer; Alain Jousten: Ondrej Schneider: and participants at the 2006 CSE conference. Pavel Dvorák provided excellent research assistance. Financial support from Grant Agency of the Czech Republic grant no. $402 / 05 / 0711$ is gratefully acknowledged. 


\section{Introduction}

Several countries have implemented, and others consider implementing, a reform of their pension system that involves a partial or complete replacement of the pay-as-you-go system with a fully funded system. The long-run benefits of a fully funded system are well known: ${ }^{1}$ while in the PAYGO system the contributions bear an implicit return equal to the rate of growth of the payroll tax base (the sum of the rates of growth of the working population and real wages), in the fully funded scheme they bear an explicit return equal to the after-tax return on capital. In a dynamically efficient economy, the rate of return on capital exceeds the rate of growth of the payroll tax base, and therefore a much lower level of contributions is needed to provide the same retirement income.

However, the fully funded system has costs as well. These include the administrative cost ${ }^{2}$ and the cost of financing the transition during which the younger cohorts would pay taxes to finance the benefits for the older cohorts as well as pay contributions to their private retirement accounts. ${ }^{3}$ Last, the fully funded system exposes future retirees to investment risk. Since stock market returns are uncertain, workers face the risk that the realized returns on accumulated contributions will not provide sufficient income during retirement. The magnitude of the investment risk has been assessed by, for example, Feldstein and Ranguelova (2001) who generate a distribution of possible histories of stock and bond market returns in the United States and the corresponding real values of an annuity that an individual would receive during retirement. If the market returns were constant all the time and equal to the average return in all years during which an individual saves for retirement, only a 3.5 percent contribution rate would be needed to sustain the current real value of pensions, as opposed to the 18 percent payroll tax rate that is needed to sustain the current real value of pensions according to the the U.S. Social Security Administration projections. However, under the 3.5 percent contribution rate there is a substantial risk that the annuity will be much below the benchmark benefits provided by the PAYGO system. Specifically, there is a 10 percent chance that the benefits will be $50 \%$ of the benchmark or lower. The contribution rates would have to be more than doubled in order to virtually eliminate the risk of an unacceptably low annuity. They also carry out expected utility comparisons and find that the individual's coefficient of relative risk aversion would have to be

\footnotetext{
${ }^{1}$ See Feldstein and Liebman (2002) for a basic exposition.

${ }^{2}$ Diamond (2000) estimates that the administrative costs of Social Security in the United States are $\$ 14.50$ per worker per year, while a system of private retirement accounts would cost $\$ 40-50$, and possibly even twice as much, depending on the particular design and the range of investment options available to workers.

${ }^{3} \mathrm{~A}$ voluminous literature is devoted to designing alternative transition mechanisms from PAYGO to fully funded schemes and evaluating their welfare effects. See for example Feldstein (2005), Joines (2005) or Conesa and Garriga (2005).
} 
rather high (around 4) in order to make the less risky PAYGO system preferable to the fully funded system. In a follow-up paper, Feldstein, Ranguelova and Samwick (2001) use the same methodology to simulate how the risk would vary across cohorts during a phased-in transition from the PAYGO system to a fully funded system. Poterba et al (2005) carry out a similar analysis for IRA accounts.

The choice between the PAYGO and fully funded system is sometimes phrased as a tradeoff between a low-return, risk-free system and a high-return (on average), high-risk system. However, the PAYGO system is not risk-free. It exposes the workers to so-called political risk, i.e., the risk that the benefits actually received will be lower than the benefits they were originally promised. The political risk has several sources. First, negative demographic or economic shocks can make the originally promised benefits infeasible at the original tax rates. Second, since the benefits are determined by the political process and there are no constraints on the government's discretion to adjust the benefits at any time, the level of benefits that a cohort was originally promised may not constitute the political equilibrium by the time the cohort retires. This may occur, for example, if the cohort loses its political power relative to other cohorts. ${ }^{4}$ Third, the PAYGO system redistributes income within a cohort, so even when a cohort receives, on average, the same benefits that it was promised, a change in the benefit formula can make the system more or less redistributive and hence cut the benefits for the relatively richer or poorer members of the cohort. Last, since the benefit formula is typically a very complex function of individual's earnings history, an adjustment in the formula may differentially affect individuals with the same total lifetime earnings but different histories of annual earnings, labor force participation, family status and other factors.

The literature on the political risk of Social Security is small but emerging. Diamond (1997) discusses the main sources of political risk and the extent to which different social security systems are insulated from such risk. McHale (2001) is the first attempt to quantify the political risk. He computes the change in social security wealth $(\mathrm{SSW})^{5}$ induced by pension reforms that were implemented in the G7 countries during the 1990's for workers with average earnings at age forty-five and at the standard retirement age. He finds that some of the reforms reduced social security wealth by as much as 29\% (the Italian 1992 reform) or 26\% (the German 1992 reform). He also finds that those at the retirement age experienced only minor, and in most cases no, cuts in benefits. McHale's contribution was valuable as it demonstrated that cuts in social security benefits do happen and they can be substantial. Shoven and Slavov (2006) take

\footnotetext{
${ }^{4}$ Mulligan and Sala-i-Martin (1999).

${ }^{5}$ Social security wealth is defined as the expected present value of social security benefits minus the expected present value of social security taxes.
} 
a more systematic look at the political risk of social security in the United States from 1939 to 2006. They compute the internal rates of return (IRR) for various age groups under the existing legislation in each year, and find "a considerable variation in the internal rates of return through time for a given birth cohort". The earlier cohorts experienced substantial increases in the IRR in the 1960's and early 1970's due to a series of tax and benefit increases and a shift to an explicit indexation of benefits. All cohorts experienced a reduction in the IRR in the 1980's and the 1990's due to subjecting benefits to taxation and other measures adopted in order to reestablish actuarial balance of the system. Blake (2004) does a similar account of reductions in IRRs for different income groups induced by a series of changes in the social security system in the United Kingdom

In this paper, we take a detailed look at a particular type of political risk faced by retirees in the Czech Republic, namely the risk due to ad-hoc indexations of benefits and changes in indexation rules. While cuts in nominal benefits for those who already collect pensions are unheard of in developed democratic countries, real benefits can be cut during periods of positive inflation by indexing benefits at a rate lower than the rate of inflation. Also, the expected present value of benefits can be cut by changing the indexation rule, for example by shifting from indexing benefits by the growth of wages to indexing benefits by the growth of prices. The Czech pension legislation only prescribes that the benefits should be adjusted annually and sets a minimum average increase that is not smaller than the inflation rate. The actual increase is at the discretion of the government and the generosity of the increase varies from year to year due to short-term considerations such as the budget deficit or the election cycle. The pension has a flat and a variable component that are increased separately. As a consequence the percentage increase in benefits differs across retiree. For example, if the variable component is increased while the fixed component remains fixed, retirees with a low pension experience a smaller percentage increase in total pension than retirees with a high pension, and may in fact experience a reduction in the real pension. Part of the risk is also cohort-specific: the distribution of pensions varies across cohorts, hence any non-uniform increase in the fixed and variable components affects different cohorts differently. Moreover, in some years the increase in benefits was explicitly different for different cohorts. Hence there is an additional dimension of risk that one's cohort will be relatively disfavored.

We use data on the distribution of new old-age pensions that were granted in the years 19881995. For each level of a newly granted pension and each cohort of retirees, we compute how the pension was indexed every year until 2006. After correcting for inflation, we obtain the real 
percentage change in pensions. ${ }^{6}$ We then employ the analysis-of-variance method to decompose the variance in individual-level percentage changes in benefits over the 1992-2006 period. We find that the variance is fairly substantial; the average change was $1.3 \log$ points but with a standard deviation of 4.3 . About $83 \%$ of the variation in percentage changes comes from year-specific shocks common to all retirees; i.e., the average generosity of real indexation varies substantially from year to year. There is very little variation due to differential treatments of different cohorts, but there is still noticable variation in the treatment of different individuals within a cohort. We also estimate the variance components due to year, cohort-year, and individual effects.

We use our estimates of the mean and standard deviation of changes in real benefits to simulate a full distribution of possible histories of PAYGO benefits. Then we compare it to the distribution of benefits that would be provided by an idealized PAYGO system where benefits would grow by a constant percentage. We also make similar comparisons with simulated histories of the evolution of benefits paid out as a variable annuity in a hypothetical fully-funded system. The major finding is that exposing retirees to the volatility in the indexation of benefits is equivalent, in the expected utility sense, to reducing benefits by 0.8 to 1.3 percent, depending on the assumed coefficient of risk aversion.

The paper is organized as follows. Section 2 provides the institutional background on the indexation of benefits within the Czech pension system and the several changes it went through since the early 1990's. Section 3 describes the data and methodology. Section 4 presents the results of the analysis of variance in the changes in benefits, and section 5 compares the distribution of benefits end expected utility under risky indexations with alternative benefit schemes. Section 6 concludes.

\section{Institutional background}

The Czech pension system is a very traditional pay-as-you-go system, with participation mandatory for all employees and the self-employed. Its design was inherited from the communist regime. ${ }^{7}$ Although the 1996 reform adjusted most of its parameters, the basic structure remained intact. ${ }^{8}$ For the cohorts covered by our data (i.e., cohorts retiring in 1988-1995) benefits

\footnotetext{
${ }^{6}$ The percentage increase in benefits has the interpretation of a percentage increase in the social security wealth under the assumption that the retiree expected to receive the previous level of real benefit for the rest of his life before the change and expects to receive the new level of real benefit for the rest of his life after the change. It can be shown that this interpretation does not depend on discounting or survival probabilities. One can therefore think of a real indexation of benefits as providing a "return" on one's SSW.

${ }^{7}$ Law No. $121 / 1975$ and 100/1988.

${ }^{8}$ The Law No. 155/1995 introduced a phased-in increase in retirement age for both men and women; it adjusted the benefit formula such that the earnings earned during all 30 years prior to retirement count; it introduced an
} 
were set under the "old" (pre-1996) legislation, the relevant elements of which we describe below.

The benefits were an increasing function of one's average gross monthly earnings from the 5 years with the highest earnings during the 10 years prior to retirement. The function was regressive such that additional earnings translated into a smaller increase in benefits, up to a maximum possible benefit. The benefit was increased by $1 \%$ with each additional year of work, and there was an extra $4 \%$ bonus for each year of work beyond the standard retirement age. The standard retirement age was 60 for men and for women it depended on the number of children such that it was 57 for women without children and each child reduced the eligibility age by one year. Importantly for future indexations, the benefit had only a variable component, increasing in the average monthly earnings; there was no fixed component such as a minimum pension that would be equal for all retirees. In 1988, the newly granted pension was CZK 1,735 per month, or 54\% of the gross average wage. ${ }^{9}$

Once granted, the benefits were fixed and the pension legislation did not provide any explicit rule for their indexation. Likewise, the past wages that entered into the computation of the income base were not indexed. Since inflation was virtually non-existent in the centrally planned Czechoslovak economy in the 1980's, this was not too much of a concern. Once in a while the benefits granted in the past were increased in an ad-hoc manner. ${ }^{10}$ Soon after the 1989 revolution the country went through a few years of rapid inflation: the consumer price index increased by 10 percent in 1990, 52 percent in 1991, 13 percent in 1992 and 19 percent in $1993 .{ }^{11}$ The government compensated retirees for increases in the cost of living by passing ad-hoc increases in benefits. First, it introduced a so-called "compensation benefit"12 in July 1990 - a flat monthly benefit of CZK 140 provided to every retiree. Formally, the compensation benefit was introduced outside of the pension system as a separate welfare payment, although for all practical purposes it was a new flat component of the pension. As inflation continued, the government kept increasing benefits at least once, and in 1991 even three times, a year. In total, there were 11 ad-hoc indexations between 1990 and 1995. The form of indexations varied widely. Some of them increased the benefits by the same amount to all retirees while some of them increased benefits by a percentage. In some instances, the indexation was not uniform across cohorts; for example, the indexation of March 1991 increased benefits by 11 percent for those who retired during or before 1978, but only by 8 percent for those who retired between 1986 and 1990. In December

explicit indexation of past wages that enter the benefit formula; it allowed early retirement; and it explicitly defined the rules for indexing benefits.

${ }^{9}$ The Statistical Yearbook of the Czech Social Security Administration, 1988, and the Czech Statistical Office.

${ }^{10}$ The Czechoslovak parliament passed such increases in 1979, 1982, 1984 (only for very low pensions) and 1988.

${ }^{11}$ The numbers reported here refer to the price index based on the consumption basket of the households of retirees.

12 "Státní vyrovnávací příspěvek" in Czech. 
1994, the compensation benefit was formally abolished, but all pensions were increased by a lump sum that exceeded the previous value of the benefit. Since then the pension has been officially divided into a flat component, common to all retirees and independent of earnings history, and a variable component which is a function of the individual's earnings history.

The 1996 pension reform laid out stable indexation rules. The new law required the government to increase the benefits each time the increase in the consumer price index accumulated since the last indexation exceeded 5\%; the increase in benefits had to equal at least $70 \%$ of the increase in the consumer price index, and at least once every two years the increase in benefits also had to include at least $33 \%$ of the growth in real wages.

The 2002 amendment of the pension law, ${ }^{13}$ still in force today, made the indexation rules simpler and more generous. The benefits are increased in January each year. The increase has to be such that the average pension increases by at least $100 \%$ of the change in the consumer price index and at least $33 \%$ of the increase in the average real wage. The law contains special provisions for years with exceptionally low and high inflation. As was the case since the early 1990's, the annual decision about indexation is made by the government.

The indexation rules expose retirees to uncertainty about the future real value of their pensions, even though their wording may leave the impression that the real benefits cannot decrease. First, the rule itself has a built-in political risk, as the realization of the real wage growth is uncertain, although one might argue the real wage growth represents only the upside of the risk. Second, there is uncertainty about the overall generosity of the increase in benefits each year. The government can, at its will, increase the benefits by more than the minimum prescribed by the law. Third, the minimum required increase in benefits is based on the increase in the price index for an average household. However, the households of retirees have different consumption patterns, and during the 1991-2005 period, the increase in the price index based on the consumption basket of the households of retirees exceeded the increase in the average price index in all years but one. ${ }^{14}$ On average, the change in the price index for retirees exceeded the change in the price index for the average household by 0.9 percentage points, and therefore the real benefit may still decrease. Fourth, in some years the indexation was cohort-specific, i.e., different cohorts explicitly received a different increase in their pension. This creates uncertainty for the retiree as to whether she belongs to a cohort that will receive relatively worse treatment.

Last, the indexation rule allows substantial heterogeneity in the actual percentage increase in benefits within each cohort. The rule does not prescribe that the fixed and variable components

\footnotetext{
${ }^{13}$ Law No. 264/2002.

${ }^{14}$ The Czech Statistical Office publishes different price indices for different types of households.
} 
of the pension must increase by an equal percentage. When the fixed component rises relative to the variable component, the indexation is relatively more generous to the poorer retirees, and when the variable component rises relative to the fixed component, the indexation is relatively more generous to the richer retirees. The government can thus use the indexation to alter the distribution of income among retirees, and in fact it does - on every single indexation decision the percentage increase in the fixed component differed from the percentage increase in the variable component. ${ }^{15}$ For an individual retiree, this creates additional uncertainty about how a given indexation decision will treat her relative to the average retiree. Also, as the indexation rule prescribes that the average pension must increase by $100 \%$ of the growth in prices and $33 \%$ of the growth in wages, retirees with a low pension might anyway experience a decline in real pension if benefits are indexed mainly by raising the variable component, whereas retirees with high pensions might still experience a decline in their real pension if benefits are indexed mainly by raising the fixed component.

Between 1990 and 2006 benefits were increased 22 times, of which the fixed component was increased on 13 occasions and the variable component was increased on 16 occasions. ${ }^{16}$ Adjustments to the fixed component are thus less frequent but when they occur they are larger, at least in percentage terms. When positive, the average nominal increase in the variable component was 6.7 percent, while the average increase in the fixed component was 45 percent, or CZK 155 in nominal terms. ${ }^{17}$

\section{Data}

In order to assess the risk involved in the indexation of benefits, we first need to know how the actual changes in benefits were distributed in the population of retirees. We use the information on the distribution of newly granted pensions reported in the Annual Yearbook of the Czech Social Security Administration. ${ }^{18}$ The yearbook reports the number of new retirees that became eligible for an old age pension within each 100CZK interval, broken down by gender. Hence the unit of observation in our data is a type of retiree characterized by gender, year of retirement (cohort), and newly granted pension. We use data for the cohorts that retired in 1988-1995. These cohorts were subject to the same pension legislation when they retired. With the 1996 pension

\footnotetext{
${ }^{15}$ For example, in 2003 the fixed component was not increased and the variable component was increased by 3.8 percent. In 2006, the fixed and variable components were increased by 5 and 4 percent, respectively.

${ }^{16}$ We count the introduction and subsequent increases in the compensation benefit as increases in the fixed component of the pension.

${ }^{17}$ This does not imply that the fixed component was growing by 49 percent annualy on average, since the fixed component was not adjusted every year.

18 "Statistická ročenka ČSSZ" in Czech.
} 
reform, the Social Security Administration changed its statistical and reporting methodology and the data on the distribution of new pensions are not available for 1996 and 1997. This is unfortunate, since many indexation decisions after 1996 provided different increases in benefits to cohorts that retired before and after the reform.

We take all government decisions on the indexation of benefits passed between 1990 and 2006, and for each type of retiree we compute his nominal pension in each month since retirement till the end of 2006. ${ }^{19}$ From this we compute his average monthly pension during a year. We convert the nominal pension into real 2005 CZK by the price index for the households of retirees, as this index more appropriately reflects the real value of pensions.

We also need to use the appropriate weights for each cohort-pension cell. We know the number of men and women in each cell in the year of retirement, and we apply the survival probabilities to obtain the number of men and women who are expected to survive to the subsequent years. ${ }^{20}$ The Social Security Administration Yearbook does not cross-tabulate the distribution of new pensions by pension and age; it only providesb the distribution of the ages of new retirees. We make the assumption that the age of retirees in each cell in the year of retirement is the average age of retirement in that year. ${ }^{21}$ In all cohorts, the average age of retirement is either 60 or 59 for men and 55 or 54 for women.

Overall, our dataset represents 718,991 people who were granted an old-age pension between 1988 and 1995, of whom 522,158 were expected to be alive in 2006 .

Figure 1 shows the evolution of the average real (in 2005 CZK) benefit for each cohort. For the cohorts that retired before 1991, we can see a sharp reduction in the real benefit due to very high inflation in 1991, and a somewhat smaller reduction in 1992 and 1993. The subsequent growth in real pensions was not sufficient, at least according to the official price index, to bring the real value of pensions back to the 1989 level. However, there are strong arguments as well as supporting empirical evidence (Hanousek and Filer 2004) that the official price index grossly overestimates the true change in the cost of living in the early 1990's. The beginning of transition

\footnotetext{
${ }^{19}$ The data reports the number of new retirees during a calendar year. Since indexations came into force in different months of the year, the month in which a retiree starts drawing a pension matters for the future increases of his pension. We make the assumption that the timing of newly claimed pensions is distributed symmetrically throughout a year, hence the average retiree starts drawing pension in a July. In the year of retirement, only indexations that come into force in July or later increase the pension in the corresponding cohort.

${ }^{20}$ We are indebted to Boris Burcin from the Charles University Demography Department for providing us with the survival probability data.. The life tables provided to us contained age-specific survival probabilities until 2004. For 2005 and 2006, we used the same values as for 2004 .

${ }^{21}$ This assumption is not entirely innocuous. The benefit formula rewards the postponement of retirement by a higher pension, generating a positive correlation between pension and the age of retirement. For this reason, the number of high-pension retirees should decline faster than average because they are older. On the other hand, the reason why they retired later may be that they are healthier, which would imply a positive relationship between pension and survival probability and thus the number of high-pension retirees would decline at a rate slower than the average.
} 
brought a large improvement in the availability, variety, and quality of all consumer goods. The composition of the consumption basket changed rapidly. The price indices for the pre-transition years do not capture various shadow costs of purchasing consumer goods in a centrally planned economy, such as queuing or bribes. For these reasons, the magnitude of the decline in the real value of pensions in 1990 and 1991 is likely to be smaller than what Figure 1 suggests. Also, the 1991 decline can hardly be attributed to the political risk originating from the government's discretion in indexing benefits. Rather, it was associated with the sharp decline in GDP that appeared to be an inevitable consequence of transition in all transition countries, and a similar reduction in the real value of pensions would likely occur in any pension system. Our analysis of the variation in changes in real benefits focuses only on the years since 1992. For these years, the measurement error in the price index is going to be much less severe.

Since indexation can be used to change the relative distribution of income among retirees, we ask whether the actual indexations tended to increase or decrease income inequality. Figure 2 plots the ratio of the 90th, 50th, and 10th percentile of the distribution of pensions in each cohort over time. It shows that the distribution was compressing rapidly during the first half of the 1990's. Since then the gap between the 10th percentile and the median remained constant while the gap between the 90th percentile and the median was increasing slightly since 2000. Somewhat ironically, the reduction in inequality occurred under the allegedly right-wing government, while inequality at the top end of the distribution increased under the social democratic government.

\section{Results}

How much variance do changes in real benefits exhibit? We computed the percentage real change in annual benefit for each retirement cohort and each level of new benefit. Figure 3 plots the real percentage change for each cohort in 1992-2006 averaged across all retirees within a cohort. The average change fluctuates between -10 and +10 percent, although most of the time when it is negative it is only slightly below zero. The volatile pattern of changes suggests that the PAYGO system hardly provided a stable and predictable source of income.

Table 1 provides summary statistics for the changes in benefits. Over the whole sample, the mean change was 1.5 percent. From the risk point of view, the more relevant parameter is the standard deviation, which is 4.3 percent, almost 3 times larger than the mean. At the extremes, there were some retirees who in some year experienced an 11 percent decline and a 25 percent increase. The middle part of the table provides information about how the distribution of returns varies across cohorts. The lowest average return for a cohort is 0.8 percent (the 1991 cohort) 
while the highest is 2.4 percent (the 1994 cohort). The last part of the table shows how the distribution of returns varied across years. The variation in the within-year standard deviation is worth noting. In 2004-2006, the standard deviation is 0.001 , which implies that all retirees receive a very similar percentage change. At the other extreme, the standard deviation was 0.026 in 1994, and the changes in benefits were spread from -5.6 percent to +25.5 percent.

Where does the variation in indexations come from? We use analysis of variance (anova) to decompose the variation due to year effects, cohort effects, cohort-year interaction effects, and the residual, that is, a random shock at each cohort-year-new pension level. In our specification the changes in benefits are generated by a process

$$
\log \left(\frac{B_{i c t}}{B_{i c t-1}}\right)=\mu+u_{t}+u_{c}+u_{c t}+\varepsilon_{i c t}
$$

where $B_{i c t}$ is a real pension of retiree $i$ in cohort $c$ in year $t, \mu$ is the mean real log change, $u_{t}, u_{c}$, and $u_{c t}$ are shocks specific to a particular year, cohort, and year-cohort interaction, respectively, and $\varepsilon_{i c t}$ is the white noise. If the $u$ 's are treated as fixed effects, the model can be estimated by a linear regression with dummy variables representing each year, cohort, and year-cohort interaction. The anova table from the regression is presented in Table 2. The model "explains" over $95 \%$ of the variation in log changes in benefits. By far most of the variation (over $83 \%$ ) is accounted for by the year effects. The volatility in the average generosity of indexations over time is the most important component of risk. The risk that an indexation formula in a given year would change benefits differently for different cohorts and different individuals in a cohort are not negligible but they are much smaller in magnitude: a little over 4 percent of the overall variation is due to cohort-year interactions and almost 5 percent is due to the residual factor. The cohort effects are also jointly significant statistically, but they are not economically important since they account for one third of one percent of the variation in changes in benefits. ${ }^{22}$ This result indicates that the indexations do not appear to systematically discriminate against some cohorts of retirees.

The fixed effects specification provides good descriptive information but does not estimate the parameters of the data generating process. Since those parameters are needed for simulations of the possible histories of indexations, we also estimate the random effects specification of equation 1. The random effects specification does not treat the values of $u_{t}$ and $u_{c t}$ as parameters of interest that should be estimated because they are given characteristics of particular years and cohorts. Rather, it treats them as draws from a distribution of possible year effects and cohort-

\footnotetext{
${ }^{22}$ For this reason, we drop the direct cohort effects when we estimate the variance components.
} 
year effects. The effects are drawn from normal distributions with mean zero and variances $\sigma_{t}^{2}$ and $\sigma_{c t}^{2}$.

The maximum likelihood estimates of the random effects model are presented in Table 3 . In the specification in column (1) all observations received equal weight; in column (2), the observations were weighted by the number of retirees behind each year-cohort-new pension observation. ${ }^{23}$ The unweighted estimate of the mean change in benefits is 0.0128 , and the estimate of the standard deviation of the year effect is 0.0436 . The fact that the standard deviation is more than three times larger than the mean effect implies that there is about a 38 percent chance that real benefits will decline on average. As expected, the cohort and and residual effects have smaller standard deviations (0.0104 and 0.0186, respectively). The weighted estimates of the mean change and the standard deviation of the year effect are very similar but the standard deviations of the cohort-year and individual effects are much smaller. The weighted estimates of the variance components are used in the simulations described below.

\section{Comparisons}

To what extent the estimated variation in changes in benefits is large or small depends on the comparison with the appropriate benchmark. First, we compare a simulated distribution of benefits in the risky PAYGO system of the Czech Republic with an idealized PAYGO system in which the real benefits are increased by the same percentage every year. Second, we compare the real-world risky PAYGO benefits with benefits paid out as a variable annuity in a hypothetical fully funded system. The value of the variable annuity is adjusted annually to reflect the appreciation or depreciation of the value of the portfolio from which the annuity is drawn. The variation in the level of the variable annuity hence provides the closest parallel to the variation in PAYGO benefits induced by indexations.

We normalize the value of the PAYGO benefit received in the first year of retirement to one. We generate 10,000 possible histories of the evolution of the benefit at the individual level over 46 years after retirement, ${ }^{24}$ assuming that the indexations are generated by equation 1 and using the estimates of the parameters $\left(\mu, \sigma_{t}, \sigma_{c t}, \sigma_{i c t}\right)$ that are reported in Table 3, column (2).

As one benchmark, we generate the evolution of benefits under an idealized, risk-free PAYGO

\footnotetext{
${ }^{23}$ The unweighted estimator was implemented by the xtmixed command in Stata; the weighted estimator, which is computationally more demanding, by the gllamm command.

${ }^{24}$ According to the 1995 survival probability tables that we used in the computations of expected utilities, the likelihood of surviving beyond age 101 is zero. Since the standard retirement age of women was 55, 46 years is the longest possible length of the collection of benefits.
} 
system in which the benefit in the first year of retirement is the same and its real value grows by $\mu \log$ points every year. Therefore, the mean benefit increases in the risky and the hypothetical risk-free PAYGO systems are the same.

The second benchmark is the variable annuity. Consider an individual in a fully funded scheme who accumulated assets $A_{R}$ in her retirement account as of the year of retirement $R$ and starts drawing the annuity in year $R+1$. The assets from which the annuity is drawn accumulate a real level return $m_{t}$ which may vary from year to year. Let the expected mean return be $\bar{m}$. The actuarially fair annuity (one for which the expected present value of annuity payments is equal to the value of assets at retirement) is then

$$
\bar{a}=\frac{A_{R}}{A P V}=A_{R} /\left(\sum_{t=R+1}^{101} \frac{S(t \mid R)}{(1+\bar{m})^{t-R}}\right),
$$

where $S(t \mid R)$ is the conditional probability of surviving until year $t$ and the term in the denominator, $A P V$, is the actuarial present value of paying out $\$ 1$ in annuity with a discount rate $\bar{m}$.

If the return $\bar{m}$ was actually realized every year, the individual would receive the same annuity every year. As the returns vary, the value of the annuity is adjusted every year to reflect the increase or decrease in the value of assets. The annuity in the first year after retirement is based on the expected mean return, hence $a_{R+1}=\bar{a}$. If return $m_{R+1}$ was realized in year $R+1$, the annuity for the next year is adjusted according to

$$
a_{R+2}=a_{R+1} \frac{1+m_{R+1}}{1+\bar{m}}
$$

Thus the annuity is increased or decreased if the realized return exceeds or falls short of the mean return. The same adjustment is done in subsequent years, therefore the variable annuity in year $R+t$ is $^{25}$

$$
a_{R+t}=\bar{a} \prod_{i=1}^{t-1}\left(\frac{1+m_{R+i}}{1+\bar{m}}\right) .
$$

Expression 3 also shows that if the return was indeed $\bar{m}$ every period, the annuity would be constant.

In the same vein as for the PAYGO benefits, we simulated 10,000 possible histories of the evolution of the variable annuity. We need to know the mean and the standard deviation of

\footnotetext{
${ }^{25}$ See Feldstein, Ranguelova, and Samwick (2001) for a derivation.
} 
the returns on the portfolio to set the inital value of the annuity appropriately. We consider a portfolio invested into stocks and bonds in the Czech capital market, which is a natural benchmark to use for comparison with the Czech PAYGO system. The portfolio is rebalanced each year to maintain a constant share $k$ of bonds. Following Feldstein, Ranguelova and Samwick (2001) we assume that the log returns on stocks and bonds are normally distributed with means $\mu_{s}, \mu_{b}$, variances $\sigma_{s}^{2}, \sigma_{b}^{2}$ and covariance $\sigma_{s b}$. Then the return on the portfolio is also lognormally distributed with a mean $\mu$ and variance $\sigma^{2}$ given by

$$
\begin{aligned}
\mu & =k\left(\mu_{b}+0.5 \sigma_{b}^{2}\right)+(1-k)\left(\mu_{s}+0.5 \sigma_{s}^{2}\right)-0.5 \sigma^{2} \\
\sigma^{2} & =k^{2} \sigma_{b}^{2}+(1-k)^{2} \sigma_{s}^{2}+k(1-k) \sigma_{s b} .
\end{aligned}
$$

We use the PX-50, the major stock index on the Prague Stock Exchange, the PBICS-100, a performance index of government and corporate bonds, ${ }^{26}$ and the consumer price index for households of retirees to estimate the mean and variance of the log returns of stock and bonds, respectively, during the 1995-2006 period. We find that the real log return on bonds has a mean 0.024 and a standard deviation 0.061 , while the real log return on stocks has a mean 0.061 and a standard deviation 0.241 . The covariance between the stock and bond real log returns is -.0003.

We simulate the evolution of the variable annuity for two alternative portfolios. The first portfolio is invested only into bonds while the second portfolio is composed of $70 \%$ bonds and $30 \%$ stocks. Note that neither of the portfolios is very conservative, since even the $100 \%$ bond portfolio contains a substantial fraction of corporate bonds, hence retirees who wish to be exposed to smaller risk may do so by choosing a pension fund that invests the accumulated assets only in government bonds. However, we are not aware of a performance index for Czech government bonds that would allow us to estimate the volatility of this less risky portfolio.

Applying the formulas in 4 and 5, the real $\log$ returns of the portfolio with a $70 \%$ share of bonds have a mean 0.042 and a standard deviation 0.083 .

The initial value of the annuity needs to be set such that it provides an appropriate comparison with the PAYGO benefits. We would argue that the appropriate comparison comes from the following thought experiment: Imagine an alternative revenue-neutral pension system in which the government, instead of paying the PAYGO benefits directly, deposits the present value of the benefits into a pension fund from which the annuity is drawn. The initial value of the annuity is then set according to equation 2 , where the accumulated assets $A_{R}$ are equal to

\footnotetext{
${ }^{26}$ The index measures the yield on investment in a portfolio of bonds coming both from the accumulation of interest on the bonds and the change in the price of bonds.
} 
the present value of benefits. In our calculation we take the present value of benefits from the idealized risk-free PAYGO where the benefits grow at constant rate of 1.37 percent every year. ${ }^{27}$ Note that the initial value of the annuity is then somewhat higher than the initial PAYGO benefit: specifically, it is 13.8 percent higher for the portfolio with a $100 \%$ share of bonds and $12.4 \%$ higher for the portfolio with a $70 \%$ share of bonds. This is possible precisely because the initial value of the annuity already reflects the expected future returns on the portfolio from which the annuity is drawn, and those returns are, on average, greater than the rate of growth of the PAYGO benefits. The inherent advantage of the funded system over PAYGO, i.e., the accumulation of interest on savings which exceeds the growth of the tax base from which the PAYGO benefits are set, applies not only to the accumulation of savings before retirement but also to the withdrawal of savings after retirement.

For the purpose of sensitivity analysis we also report more conservative results for an annuity the initial value of which is equal to the initial value of the benefit. By construction the expected present value of this annuity is however lower than the present value of the PAYGO benefits.

We provide two comparisons of risk between the real-world PAYGO system and alternative systems. The first comparison looks at the probability that the PAYGO benefits would fall to a level that is deemed too low compared to the benchmark at some point during retirement. Specifically, we compute the ratio of the PAYGO benefit to the benchmark benefit 10 years after retirement for each of the 10,000 simulated histories. Table 4 shows the percentiles of the distribution of the PAYGO benefits relative to different benchmarks. Column (1) reports the distribution of PAYGO benefits relative to an idealized, risk-free PAYGO in which the real benefits are increased by the same percentage every year. Since the average increase in benefits under the risky PAYGO is the same, the two systems differ only in the variance, and there is an equal chance that the benefits under the risky PAYGO will be higher as well as lower than under the risk-free PAYGO. There is a $25 \%$ probability that 10 years after retirement the benefits will be 92 percent or less than the risk-free benefits, and a $5 \%$ chance that the benefits will be only $81 \%$ or less than the risk free benefits.

Since the stock and bond market returns have larger variance than the PAYGO benefit returns, the comparisons with the variable annuity (columns (2) through (5)) exhibit larger probabilities of both very favorable and very unfavorable outcomes. If one considers a variable annuity drawn from a portfolio which has a $70 \%$ share of bonds as an alternative source of pension, with a $25 \%$ probability the PAYGO benefits would be $89 \%$ of the variable annuity or less,

\footnotetext{
${ }^{27}$ The benefits are discounted by the survival probabilities and the discount rate equal to the mean return of the portfolio $\bar{m}$.
} 
and with a $5 \%$ probability they would be as low as $68 \%$ of the variable annuity or less. The percentiles are somewhat closer to 1 if the comparison is made with a variable annuity drawn from a portfolio invested entirely in bonds (column (3)); since the bonds are less risky, there is a smaller likelihood of realizing a sequence of very high returns which would allow the payments of an annuity much higher than the PAYGO benefits. Note that there is also a non-negligible likelihood that the PAYGO benefits would substantially exceed the variable annuity. Specifically, with a $5 \%$ probability the PAYGO benefit could exceed the variable annuity by $70 \%$ or $48 \%$, depending on the assumed share of bonds in the portfolio.

Finally, columns (4) and (5) provide a more conservative comparison with a variable annuity whose initial value is reduced to equal the PAYGO benefit. By construction the distribution of relative outcomes is more favorable for the PAYGO. There is only a $25 \%$ chance that the PAYGO benefit would be below the variable annuity benefit, and a $5 \%$ chance that the benefit would be below $77 \%$ of the variable annuity (if the latter is based on a $70 \%$ bond portfolio).

While comparing the level of benefits 10 years after retirement provides a simple and illustrative description of the riskiness of PAYGO relative to other schemes, it does not capture the evolution of benefits during the full length of retirement and does not provide any measure of how much worse off the retirees are because of the uncertainty in the level of benefits. We therefore provide expected utility comparisons between the risky PAYGO and the benchmark. The comparisons are based on the constant-relative-risk-aversion utility function

$$
\begin{aligned}
U_{h t} & =\frac{B_{h t}^{1-\sigma}}{1-\sigma} \\
E U & =\sum_{h} p_{h}\left(\sum_{t=R+1}^{100} U_{h t} \frac{S(t \mid R)}{(1+\delta)^{t-R}}\right)
\end{aligned}
$$

where $\sigma$ is the coefficient of relative risk aversion, $\delta$ is the discount rate, and the first summation is over all possible realizations of histories of retirement benefits $B_{h t}$, with $p_{h}$ denoting the probability of history $h$ being realized. ${ }^{28}$ The constant relative risk aversion utility function has the advantage that the equivalent consumption comparisons between streams of benefits can be expressed in terms of percentages of consumption that are invariant to the scaling of benefits. For example, the expected utility under risky PAYGO can be compared with the expected utility under an idealized risk-free PAYGO by asking by what percentage the benefits under the riskfree PAYGO would have to be cut in every period so that both systems would provide the same

\footnotetext{
${ }^{28}$ The drawback of our computation is that the retirees are implicitly assumed to simply consume the benefits every period. Modeling the adjustments of savings and consumption to shocks in the benefit level is beyond the scope of this paper and would potentially require very ad-hoc assumptions about the ability of retirees to insure against volatility in PAYGO benefits.
} 
expected utility. ${ }^{29}$

We computed the expected utilities from our simulations of 10,000 histories of stock market returns and indexations of social security benefits, and from these we computed the percentage change in consumption under the benchmark systems that would equalize the expected utilities with the risky PAYGO. The assumed discount rate was 0.04 . The survival probabilities were those for men who retired at age 60 in 1995, the last cohort in our sample. The equivalent consumption is sensitive to the choice of the coefficient of relative risk aversion; in Table 5, the results are reported for the values of $\sigma=2$ and $\sigma=3 .^{30}$

The entries in columns (1) and (2) report the crucial result. Compared to the risk-free PAYGO, exposing the retirees uncertain volatility of the indexation of benefits is equivalent to cutting benefits by 0.8 percent (if $\sigma=2$ ) or 1.3 percent (if $\sigma=3$ ). In other words, the retirees are equally well off under the current risky PAYGO as they would be under the PAYGO in which the benefits would grow at a constant rate, but the initial level of the benefit and consequently its levels after all future indexations would be reduced by 0.8 or 1.3 percent. Seen from a different angle, the government could save this amount every year on social security benefits without making the retirees worse off if it were able to guarantee a constant growth of real benefits.

The remaining entries in Table 5 show the comparison between the risky and risk-free PAYGO and the variable annuities. Even though the initial value of the annuity is greater, the variable annuity turns out to provide lower expected utility at our assumed values of $\sigma$. For example, even in the scenario most favorable for the variable annuity (the portfolio invested only in bonds and $\sigma=2$, reported in (5)), the expected utility from the risky PAYGO is $1.9 \%$ higher than the expected utility from a variable annuity in terms of equivalent consumption.

However, the gap between the equivalent consumption comparisons of the variable annuity with the risk-free and risky PAYGO is more relevant than the equivalent consumption levels themselves. Most comparisons between the PAYGO and the fully funded schemes assume that the level of PAYGO benefits is certain. The gap shows how large an error one makes by failing to account for the political risk of the PAYGO. For example, column (6) shows that, for an individual with $\sigma=3$, the expected utility from the risk-free PAYGO is $3.7 \%$ higher (in terms

\footnotetext{
${ }^{29}$ That is, if $B_{r h t}$ denotes the benefits from risky PAYGO under a particular realization of history $h$ and $B_{i h t}$ benefits under risk-free PAYGO, then increasing $B_{i h t}$ by $\alpha$ percent would equalize the expected utilities from the two systems:

$$
\sum_{h} p_{h}\left(\sum_{t=R+1}^{100} \frac{B_{r h t}^{1-\sigma}}{1-\sigma} \frac{S(t \mid R)}{(1+\delta)^{t-R}}\right)=\sum_{h} p_{h}\left(\sum_{t=R+1}^{100} \frac{(1+\alpha) B_{i h t}^{1-\sigma}}{1-\sigma} \frac{S(t \mid R)}{(1+\delta)^{t-R}}\right) .
$$

The sign of $\alpha$ determines which scheme provides a higher expected utility.

${ }^{30}$ Values in this range are also used in Poterba et al. (2003).
} 
of equivalent consumption) than the expected utility from the variable annuity drawn from a portfolio invested entirely in bonds. However, that difference is reduced to $2.4 \%$ of equivalent consumption if one makes the appropriate comparison with the risky PAYGO. The difference between these too equivalent variation comparisons is virtually identical to the direct equivalent variation comparison of $1.3 \%$ between the risk-free and the risky PAYGO. For the same value of $\sigma$, the same difference in equivalent variation comparisons is found for the alternative composition of the portfolio and the initial value of the variable annuity.

\section{Conclusions}

It has been well recognized that changes in the indexation of benefits expose retirees to political risk, and several papers (McHale 2001 and Shoven and Slavov 2006, for example) have documented by how much specific legislative changes, such as a switch from wage indexation to price indexation, have affected the social security wealth or the internal rates of return from social security contributions for selected types of workers in several countries. In fact, the indexation of benefits is the only aspect of the pension system that affects the future incomes of people who have already retired. Since retirees are numerous (19\% of Czech citizens were collecting an old-age pension in 2005), the generosity and volatility of future indexations are important determinants of the living standards for a large fraction of the population.

In this paper we analyzed the risk involved in the indexation of benefits as actually implemented in the Czech Republic since the early 1990's. The Czech case is particularly interesting since the pension legislation does not prescribe a formula for indexation but rather leaves some discretion to the government. We used the data on the distribution of new old-age pensions in the cohorts retiring between 1988-1995 and the legislative ruling governing the annual indexations of benefits to compute the entire distribution of annual changes in real benefits. We showed that the changes are fairly volatile and that much of the variation in the changes at the individual level can be attributed to the variation in the average generosity of indexation over time.

We used our estimates to simulate 10,000 possible histories of the evolution of PAYGO benefits in order to compare the political risk of PAYGO benefits with the investment risk of the benefits provided through a variable annuity. We also assessed the magnitude of the political risk in comparison with an idealized PAYGO system in which the benefits grow at a constant rate. We found that the political risk effectively reduces the expected utility of retirees by approximately one percent of equivalent consumption. While it is not a dramatic number, we would argue it is large enough to be taken into account when quantifying the relative benefits and costs of 
the pay-as-you-go pension system and various reform options. Moreover, the risk involved in the indexation of benefits is arguably a smaller component of the overall political risk of social security. The methodology laid out in this paper can be extended to assess the political risk that affects the future level of benefits or taxes of the workers who have not yet retired, which opens an important agenda for future research. 


\section{References}

[1] Blake, David: What is a Promise from the Government Worth? Measuring and Assessing Political Risk in State and Personal Pension Schemes in the United Kingdom, Pensions Institute Discussion Paper PI-0409, September 2004.

[2] Conesa, Juan Carlos, and Carlos Garriga: Optimal Design of Social Security Reforms, CREA Working Paper \#140, 2005.

[3] Diamond, Peter: Insulation of Pensions from Political Risk, in Valdes-Prieto Salvador (ed.): The Economics of Pensions: Principles, Policies, and International Experience, Cambridge University Press, 1997.

[4] Diamond, Peter: Administrative Costs and Equilibrium Charges with Individual Accounts, published in Shoven, John B.: Administrative aspects of investment-based social security reform, University of Chicago Press, 2000.

[5] Feldstein, Martin and Jeffrey Liebman: Social Security, in Aurebach, Alan J. and Martin Feldstein: Handbook of Public Economics, Volume 3, North-Holland/Elsevier, 2002.

[6] Feldstein, Martin: Structural Reform of Social Security, Journal of Economic Perspectives, Vol. 19, No. 2, pp. 33-55, Spring 2005

[7] Feldstein, Martin and Elena Ranguelova: Individual Risk in an Investment-based Social Security System, American Economic Review, Vol. 91, No. 4, pp. 1116-1125, September 2001.

[8] Feldstein, Martin, Elena Ranguelova and Andrew Samwick: The Transition to InvestmentBased Social Security When Portfolio Returns and Capital Profitability Are Uncertain, in Campbell, John Y. and Martin Feldstein (eds.): Risk Aspects of Investment-Based Social Security Reform, University of Chicago Press, 2001.

[9] Hanousek, Jan, and Randall C. Filer: Consumers' Opinion of Inflation Bias Due to Quality Improvements, Economic Development and Cultural Change, Vol. 53, No.1, pp. 235-254, February 2004.

[10] Joines, Douglas H.: Pareto-Improving Social Security Reform, 2005 Meeting Papers 396, Society for Economic Dynamics, 2005.

[11] Leimer, D: Cohort Specific Measures of Lifetime Net Social Security Transfers, working paper no. 59, Office of Research and Statistics, Social Security Administration, 1994. 
[12] McHale, John: The Risk of Social Security Benefit-Rule Changes: Some International Evidence, in Campbell, John Y. and Martin Feldstein: Risk Aspects of Investment-Based Social Security Reform, University of Chicago Press, 2001.

[13] Mulligan, Casey B. and Xavier Sala-i-Martin: Gerontocracy, Retirement, and Social Security, NBER working paper 7117, May 1999.

[14] Mulligan, Casey B. and Xavier Sala-i-Martin: Political and Economic Forces Sustaining Social Security, Advances in Economic Analysis and Policy, Vol. 4, No. 1, May 2004.

[15] Poterba, James, Joshua Rauh, Steven Venti, and David Wise: Utility Evaluation of Risk in Retirement Saving Accounts, in Wise, David (ed.): Analyses in the Economics of Aging, University of Chicago Press, 2005.

[16] Schieber, Sylvester J., and John B. Shoven: Administering a Cost-Effective National Program of Personal Security Accounts, in Shoven, John B.: Administrative Aspects of Investment-Based Social Security Reform, University of Chicago Press, 2000.

[17] Shoven, John and Sita N. Slavov: Political Risk versus Market Risk in Social Security, NBER Working Paper no. 12135, March 2006. 


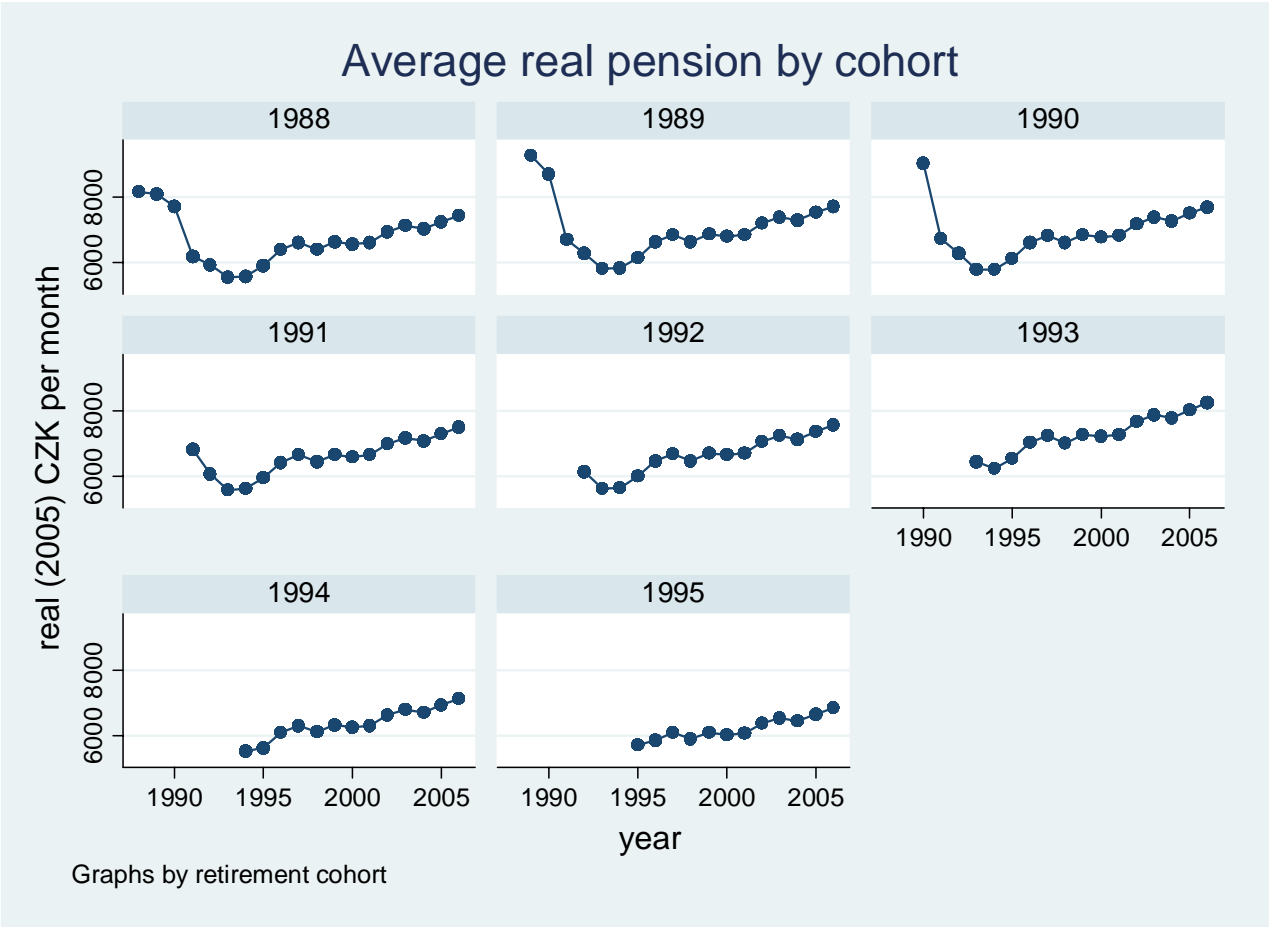

Figure 1: 
Inequality of pensions by cohort over time

Ratio of the 90th, 50th, and 10th percentile to the average pension

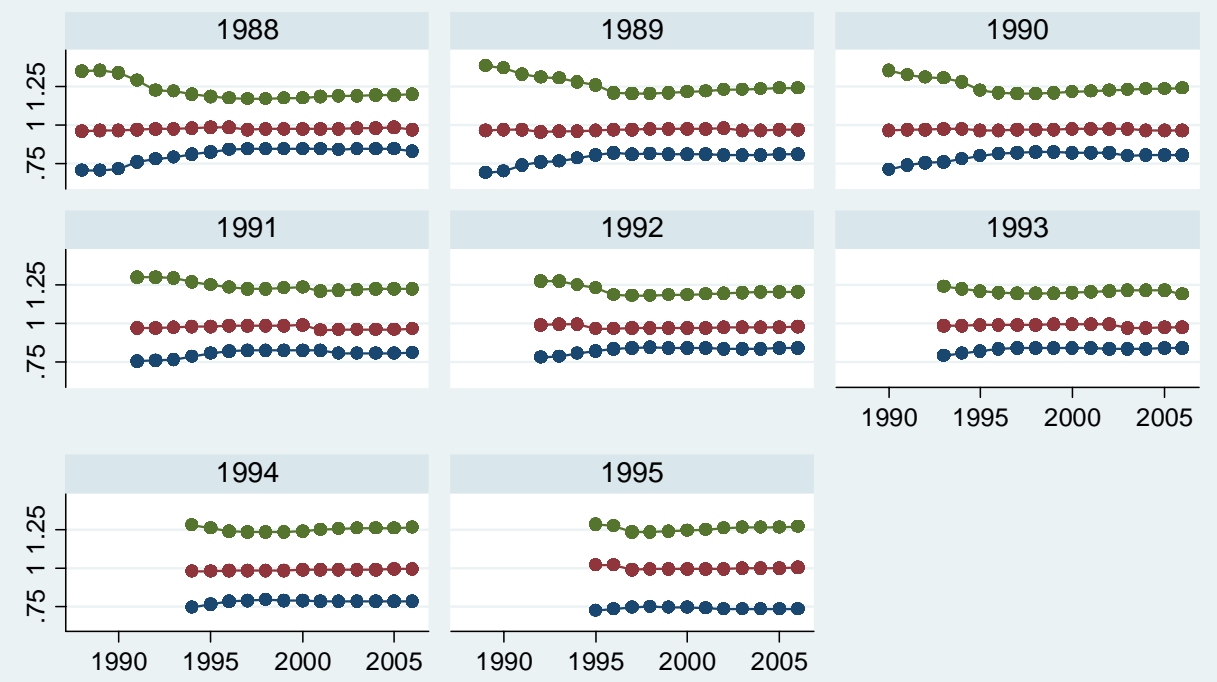

Graphs by retirement cohorts

Figure 2: 


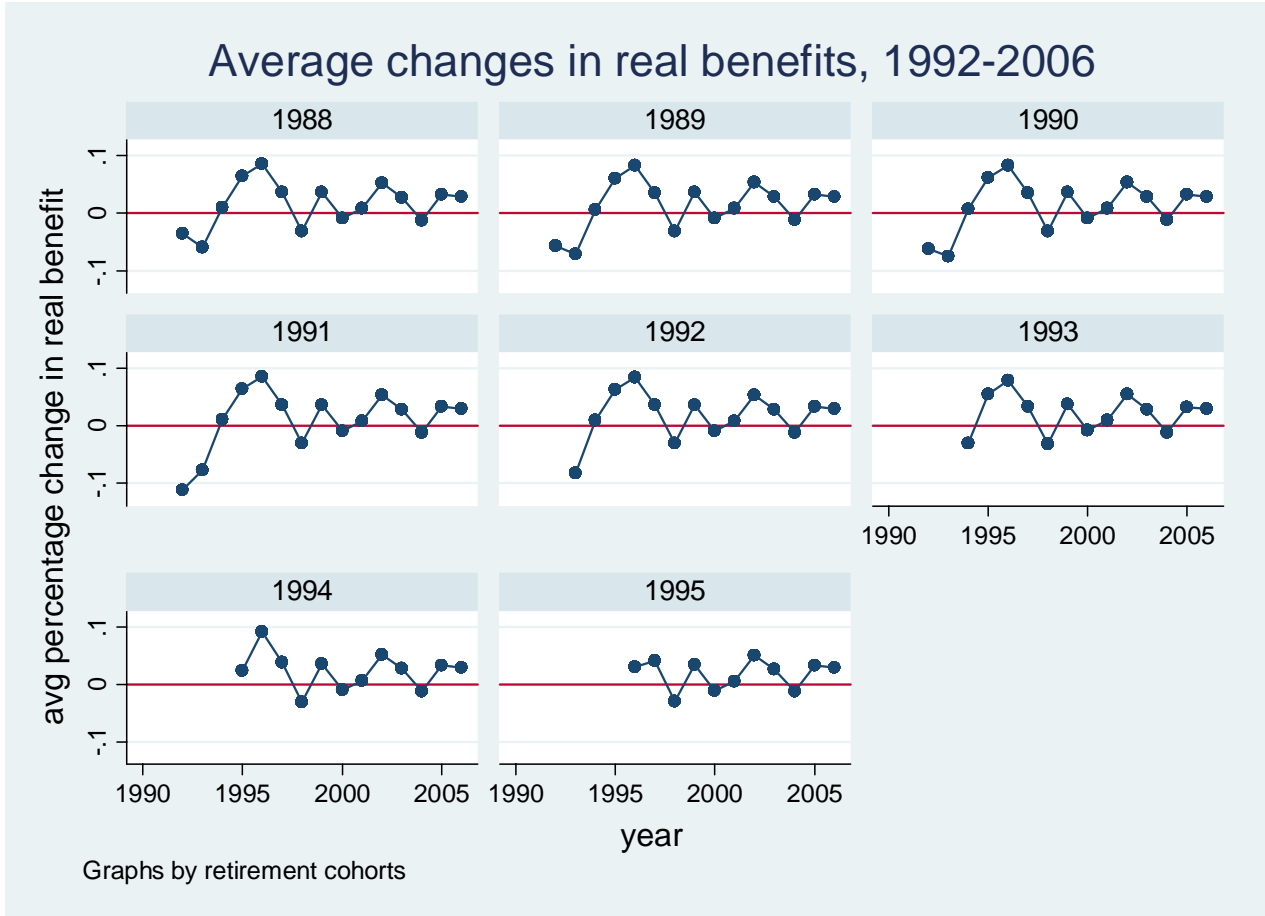

Figure 3: 
Table 1

Changes in real benefits from indexations, summary statistics 1992-2006

\begin{tabular}{|c|c|c|c|c|c|}
\hline All cohorts and years & $\begin{array}{r}\text { observations } \\
8.553 .162\end{array}$ & $\begin{array}{l}\text { mean } \\
0.015\end{array}$ & $\begin{array}{l}\text { st.dev. } \\
0.043\end{array}$ & $\begin{array}{l}\min \\
-0.114\end{array}$ & $\begin{array}{l}\max \\
0.255\end{array}$ \\
\hline \multicolumn{6}{|l|}{ By cohort } \\
\hline 1988 & 827,658 & 0.015 & 0.041 & -0.077 & 0.152 \\
\hline 1989 & $1,382,831$ & 0.012 & 0.044 & -0.082 & 0.165 \\
\hline 1990 & $1,154,735$ & 0.011 & 0.045 & -0.085 & 0.168 \\
\hline 1991 & $1,496,849$ & 0.008 & 0.053 & -0.114 & 0.240 \\
\hline 1992 & $1,220,989$ & 0.017 & 0.043 & -0.087 & 0.255 \\
\hline 1993 & 952,400 & 0.021 & 0.034 & -0.056 & 0.145 \\
\hline 1994 & 747,880 & 0.024 & 0.033 & -0.033 & 0.175 \\
\hline 1995 & 769,820 & 0.018 & 0.026 & -0.035 & 0.133 \\
\hline
\end{tabular}

By year

$\begin{array}{rrrrrr}1992 & 377,867 & -0.070 & 0.031 & -0.114 & 0.092 \\ 1993 & 468,768 & -0.074 & 0.009 & -0.087 & -0.015 \\ 1994 & 541,332 & 0.003 & 0.026 & -0.056 & 0.255 \\ 1995 & 599,749 & 0.057 & 0.024 & -0.016 & 0.246 \\ 1996 & 664,242 & 0.078 & 0.023 & 0.012 & 0.204 \\ 1997 & 652,046 & 0.036 & 0.008 & 0.020 & 0.118 \\ 1998 & 639,242 & -0.031 & 0.001 & -0.034 & -0.017 \\ 1999 & 626,405 & 0.037 & 0.003 & 0.009 & 0.043 \\ 2000 & 613,156 & -0.009 & 0.002 & -0.033 & -0.004 \\ 2001 & 599,306 & 0.008 & 0.004 & -0.035 & 0.017 \\ 2002 & 585,125 & 0.053 & 0.005 & 0.004 & 0.063 \\ 2003 & 570,345 & 0.028 & 0.002 & 0.008 & 0.031 \\ 2004 & 554,595 & -0.012 & 0.001 & -0.024 & -0.010 \\ 2005 & 538,826 & 0.033 & 0.001 & 0.032 & 0.040 \\ 2006 & 522,158 & 0.029 & 0.000 & 0.024 & 0.030\end{array}$


Table 2

Analysis of variance in changes in real benefits, 1992-2006

Specification: year, cohort, and interaction effects

\begin{tabular}{|c|c|c|c|c|c|c|}
\hline \multirow[t]{2}{*}{$\begin{array}{l}\text { Observations } \\
\text { Root MSE }\end{array}$} & \multicolumn{2}{|l|}{$\begin{array}{r}8,553,162 \\
0.00930\end{array}$} & \multicolumn{2}{|c|}{$\begin{array}{l}\mathrm{R}^{\wedge} 2 \\
\text { Adj. } \mathrm{R}^{\wedge} 2\end{array}$} & $\begin{array}{l}0.9528 \\
0.9528\end{array}$ & \multirow[b]{2}{*}{ Fraction of total SS } \\
\hline & Partial SS & df & MS & $\mathrm{F}$ & Prob $>F$ & \\
\hline model & 14,937 & 109 & 137.04 & $1,600,000$ & 0.000 & \\
\hline year & 13,027 & 14 & 930.50 & $11,000,000$ & 0.000 & 0.831 \\
\hline cohort & 55 & 7 & 7.81 & 90,337 & 0.000 & 0.003 \\
\hline cohort*year interaction & 674 & 88 & 7.66 & 88,592 & 0.000 & 0.043 \\
\hline residual & 739 & & 0.00009 & & & 0.047 \\
\hline total & 15,677 & & 0.00183 & & & \\
\hline
\end{tabular}

Specification: year and interaction effects

\begin{tabular}{|c|c|c|c|c|c|c|}
\hline \multirow[t]{2}{*}{$\begin{array}{l}\text { Observations } \\
\text { Root MSE }\end{array}$} & \multicolumn{2}{|l|}{$\begin{array}{r}8,553,162 \\
0.00930\end{array}$} & \multicolumn{2}{|r|}{$\begin{array}{l}\mathrm{R}^{\wedge} 2 \\
\text { Adj. } \mathrm{R}^{\wedge} 2\end{array}$} & $\begin{array}{l}0.9528 \\
0.9528\end{array}$ & \multirow[b]{2}{*}{ Fraction of total SS } \\
\hline & Partial SS & $\mathrm{df}$ & MS & $\mathrm{F}$ & Prob $>F$ & \\
\hline model & 14,937 & 109 & 137.04 & $1,600,000$ & 0.000 & \\
\hline year & 13,182 & $\begin{array}{l}14 \\
95\end{array}$ & $\begin{array}{r}941.58 \\
789\end{array}$ & $\begin{array}{r}11,000,000 \\
-01,258\end{array}$ & 0.000 & 0.841 \\
\hline $\begin{array}{l}\text { cohort*year interaction } \\
\text { residual }\end{array}$ & $\begin{array}{r}750 \\
739 \\
\end{array}$ & 95 & $\begin{array}{r}7.89 \\
0.00009 \\
\end{array}$ & 91,258 & 0.000 & $\begin{array}{l}0.048 \\
0.047 \\
\end{array}$ \\
\hline total & 15,677 & & 0.00183 & & & \\
\hline
\end{tabular}


Table 3

Variance components of changes in real benefits, 1992-2006

$\begin{array}{lccc} & & (1) & (2) \\ \text { constant } & & \text { unweighted } & \text { weighted } \\ & (\mu) & 0.0128 & 0.0137 \\ & & (0.0113) & (0.0105) \\ \text { year effect } & \left(\sigma_{\mathrm{t}}\right) & 0.0436 & 0.0428 \\ \text { cohort-year effect } & & (0.0083) & (0.0006) \\ & \left(\sigma_{\mathrm{ct}}\right) & 0.0104 & 4.802 \mathrm{E}-07 \\ \text { residual } & & (0.0008) & (2.018 \mathrm{E}-13) \\ & \left(\sigma_{\text {ict }}\right) & 0.0186 & 9.053 \mathrm{E}-07 \\ & & (0.0002) & (7.172 \mathrm{E}-13)\end{array}$

Notes: Standard errors in parantheses. The dependent variable is the log change in real benefit. The unit of observation is year-cohort-new pension. 
Table 4

Distribution of benefits under the risky PAYGO system 10 years after retirement as a fraction of benefits under a benchmark system

(1)

Benchmark:

Risk-free

PAYGO

N/A

0.74

0.81

0.85

0.92

1.00

1.09

1.18

1.23

1.35

1.01

mean

std. dev.

share of bonds

percentile

$25 \%$

$75 \%$

$95 \%$

$99 \%$

0.13
(2)

(3)

Variable annuity with the same expected

PV of benefits
(4)

(5)

Variable annuity with the same initial benefit

0.57

0.62

0.71

0.77

0.88

1.03

1.19

1.36

1.48

1.71

$70 \%$

$100 \%$

0.89

0.77

0.70

1.28

1.53

1.70

2.09

1.05

0.85

1.00

1.20

1.44

1.72

1.91

2.34

0.81

0.88

1.00

1.17

1.35

1.55

1.68

1.95

1.11

0.24

1.25

1.20

0.32

0.36

0.27 
Table 5

Equivalent variation comparisons between alternative systems
(1)
(2)
(3)
(4) (5)
(6)

coefficient of relative risk aversion

share of bonds in the portfolio

$\begin{array}{cccccc}2 & 3 & 2 & 3 & 2 & 3 \\ \text { N/A } & \text { N/A } & 70 \% & 70 \% & 100 \% & 100 \% \\ & & & & & \\ -0.8 \% & -1.3 \% & & & & \end{array}$

Risk-free PAYGO compared with variable annuity that provides the same expected PV of benefits

$\begin{array}{llll}8.4 \% & 11.5 \% & 2.7 \% & 3.7 \% \\ & & & \\ 7.7 \% & 10.1 \% & 1.9 \% & 2.4 \% \\ & & & \\ 21.8 \% & 25.3 \% & 16.9 \% & 18.1 \% \\ & & & \\ 21.0 \% & 23.7 \% & 16.0 \% & 16.5 \%\end{array}$

Risky PAYGO compared with variable annuity that provides the same initial benefit

Risky PAYGO compared with variable annuity that provides the same expected PV of benefits

Risk-free PAYGO compared with variable annuity that provides the same initial benefit

$21.0 \% \quad-23.7 \% \quad 16.0 \% \quad-16.5 \%$

Notes: The entries in the table are percentage increases in benefits in the latter system required to provide the same expected utility as the former system. 
Individual researchers, as well as the on-line and printed versions of the CERGE-EI Working Papers (including their dissemination) were supported from the following institutional grants:

- Economic Aspects of EU and EMU Entry [Ekonomické aspekty vstupu do Evropské unie a Evropské měnové unie], No. AVOZ70850503, (2005-2010);

- Economic Impact of European Integration on the Czech Republic [Ekonomické dopady evropské integrace na ČR], No. MSM0021620846, (2005-2011);

Specific research support and/or other grants the researchers/publications benefited from are acknowledged at the beginning of the Paper.

(c) Libor Dušek, 2007.

All rights reserved. No part of this publication may be reproduced, stored in a retrieval system or transmitted in any form or by any means, electronic, mechanical or photocopying, recording, or otherwise without the prior permission of the publisher.

Published by

Charles University in Prague, Center for Economic Research and Graduate Education (CERGE) and

Economics Institute ASCR, v. v. i. (EI)

CERGE-El, Politických vězňŭ 7, 11121 Prague 1, tel.: +420 224005 153, Czech Republic.

Printed by CERGE-EI, Prague

Subscription: CERGE-EI homepage: http://www.cerge-ei.cz

Editors: Directors of CERGE and EI

Managing editors: Deputy Directors for Research of CERGE and EI

ISSN 1211-3298

ISBN 978-80-7343-115-0 (Univerzita Karlova. Centrum pro ekonomický výzkum

a doktorské studium)

ISBN 978-80-7344-104-3 (Národohospodářský ústav AV ČR, v. v. i.) 
CERGE-EI

P.O.BOX 882

Politických vězňů 7

11121 Praha 1

Czech Republic http://www.cerge-ei.cz 